1. Kryminal'nyy protsesual'nyy kodeks Ukrayiny [Criminal Procedural Code of Ukraine]. Vidomosti Verkhovnoyi Rady Ukrayiny (VVR), 2013, № 9-10, № 11-12, № 13, st. 88. URL : https://zakon.rada.gov.ua/laws/show/4651-17?find=1\&text=\%D1\%81\%D1\%82+242\#w14978. [in Ukr.]

2. Instruktsiya pro pryznachennya ta provedennya sudovykh ekspertyz [Instruction on the appointment and conduct of judicial examinations], zatverdzhena nakazom Ministerstva yustytsiyi Ukrayini № 53/5 vid 08.10.1998 r. URL : https://zakon.rada.gov.ua/laws/show/z0705-98. [in Ukr.]

3. Pro sudovu ekspertyzu: Zakon Ukrayiny [On Forensic examination]. Vidomosti Verkhovnoyi Rady Ukrayiny, 1994, № 28, st.232 № 4038-KHII. URL : https://zakon5.rada.gov.ua/laws/show/4038-12. [in Ukr.]

4. Stepanyuk, R. L. (2012) Vykorystannya spetsial'nykh znan' pid chas rozsliduvannya zlochyniv u byudzhetniy sferi Ukrayiny [Use of specialized knowledge in the investigation of crimes in the budgetary area of Ukraine]. Kryminalistychnyy visnyk. № 17. C. 102-108. [in Ukr.]

5. Polozhennya pro medyko-sotsial'nu ekspertyzu [Regulations on medical and social examination] vid 3 hrudnya 2009 r. № 1317. URL : https://zakon.rada.gov.ua/laws/show/1317-2009-\%D0\%BF. [in Ukr.]

6. Shcherbakovs'kyy, M. H. (2015) Provedennya ta vykorystannya sudovykh ekspertyz u kryminal'nomu provadzhenni [Conducting and using forensics in criminal proceedings]: monohrafiya. Kharkiv : KhNUVS, 560 s. [in Ukr.]

7. Zapotots'kyy, A. P. (2017) Vykorystannya spetsial'nykh znan' pid chas vstanovlennya obstavyn, shcho mayut' znachennya pry rozsliduvani zlochyniv u sferi budivnytstva [Use of Special Knowledge in Determining Circumstances of Importance in Investigating Construction Crimes]. Naukovyy visnyk publichnoho ta pryvatnoho prava. Vyp. 2, S. 236-243. [in Ukr.]

8. Chernyavs'kyy, S. S. (2016) Aktual'ni problemy pryznachennya sudovo-ekonomichnykh ekspertyz ta dokumental'nykh reviziy u kryminal'nomu provadzhenni [Actual problems of appointment of forensic expertise and documentary audits in criminal proceedings]. Aktual'ni pytannya vykorystannya mozhlyvostey pozaplanovykh dokumental'nykh reviziy ta inshykh perevirok u kryminal'nomu sudochynstvi : Mizhvid. nauk.-prakt. sem. Kyyiv : NAVS, S 123-127. [in Ukr.]

\title{
Summary
}

The scientific article explores the issues of determining the most important types of forensic expertise to be assigned in the investigation of crimes related to illegal use of budget funds in the field of health care. Regulatory acts and opinions of leading scientists on the subject were analyzed.

Keywords: forensics expertise, crime investigations, budget crimes, healthcare, pre-trial investigation.

UDC 343.221.51

DOI: $10.31733 / 2078-3566-2019-5-232-237$

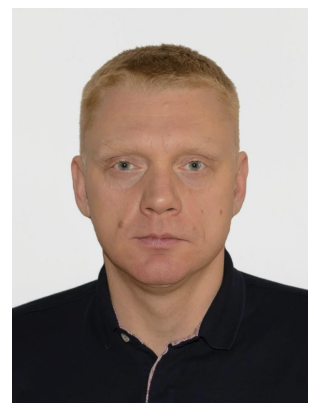

Mykola KRIZHANOVSKY ${ }^{\odot}$

Post-graduate

(Kharkiv National University of Internal Affairs)

\section{MEASURES OF CRIMINAL LEGAL NATURE FOR LEGAL ENTITIES: PREREQUISITES, GROUNDS AND CONDITIONS OF APPLICATION}

МикоЛа КрИжаНовський. ЗАХОДИ КРИМІНАЛЬНО-ПРАВОВОГО ХАРАКТЕРУ ЩОДО ЮРИДИЧНИХ ОСІБ: ПШСТАВИ ТА УМОВИ ЗАСТОСУВАННЯ. ВиЗНачено ПідставИ Та умови застосування заходів кримінального характеру стосовно юридичних осіб, а також передумови, підстави та порядок застосування заходів щодо подальшого кримінального провадження стосовно юридичних осіб. Проведено ознайомлення зі змістом окремих положень розділу XIV-I Загальної частини Кримінального кодексу України щодо застосування примусових заходів кримінального характеру стосовно юридичних осіб (штраф, конфіскація майна та ліквідація).

Розглянуто актуальні в цьому контексті питання та зроблено наступні висновки: 1) заходи кримінального характеру стосовно юридичних осіб розглядаються сукупно: а) примусові заходи кримінального характеру стосовно юридичних осіб (штраф, конфіскація майна, ліквідація); б) заходи, засновані на необгрунтованості здійснення подальших кримінальних проваджень щодо юридичної особи (звільнення юридичної особи від застосування заходів кримінального характеру); 2) застосування примусових заходів кримінального характеру по відношенню до юридичної особи можливо не тільки за наявності підстав, встановлених судом застосування таких заходів, але і за відсутності обставин, що перешкоджають прийняттю рішення про застосування таких заходів до юридичної особи, а також підстави звільнення юридичної особи від застосування

(C) Krizhanovsky M., 2019

ORCID iD : https://orcid.org/0000-0001-8847-0557

k_kpk@dduvs.in.ua 
примусових заходів кримінального характеру; 3) причинно-факторний комплекс реалізації заходу, що грунтується на необгрунтованості подальшого кримінального провадження стосовно юридичної особи, є сукупністю передумов та підстав, змістом яких є поєднання певної події та відповідної поведінки особи разом із констатацією певної обставини.

Ключові слова: юридична особа, передумова, підстава, умова, застосування, заходи кримінально-правового характеру.

Problem statement. Part 2 of the Article 4 of the Criminal Code of Ukraine (hereinafter referred to as the Criminal Code of Ukraine) declares that crime and punishment, as well as other criminal consequences of the act are determined by the law on criminal liability of Ukraine. Such criminal consequences of an act are the forcible consequences or those ones based on the unreasonableness of further criminal proceedings, measures of criminal nature in relation to legal entities.

In the Criminal Code of Ukraine, these other consequences are regulated in section XIV-I "Measures of Criminal Law on Legal Entities". The content of such forcible measures (fine, confiscation of property and liquidation) implies certain restrictions on the property or organizational legal nature. Measures, provided in Article 96-5 of the Criminal Code of Ukraine, are unreasonable to carry out further criminal proceedings against a legal entity due to the inability to sufficiently execute a preventive influence on a legal entity as a subject of criminal legal relations due to the expiration of limitation periods. The practical implementation of these measures of criminal nature in relation to legal entities establishes preconditions, grounds and conditions determined by law. There is no consensus in the doctrine of criminal law regarding the cause-and-effect implementation of measures of criminal and law nature. In this connection it would be desirable to draw the scientists' attention to the discussion regarding the definition of the preconditions, grounds and application of both compulsory conditions and those ones based on the unreasonableness of carrying out further criminal proceedings, measures of criminal nature in relation to legal entities.

Analysis of publications that started solving this problem. Investigations of measures of criminal nature in relation to legal entities have been in the sphere of attention of Grishchuk, Paseki, Panchenko, Provotorov. Some of the components were considered in the broader context of the study of the institute of criminal and law measures in the papers by Zaginy, Kozachenko, Mitrofanov, Knizhenko, Orlovskaya, Khavroniuk, Yashchenko and many other scientists. While giving due value to the scientific researches of the mentioned authors, it should be noted that many issues of the aforementioned problems remain to be solved and the solutions of some of them are not indisputable. Exactly such issues include the question of establishing the preconditions, grounds and application of both forcible conditions and those ones based on the unreasonableness of carrying out further criminal proceedings, measures of criminal nature in relation to legal entities.

The article's objective is to determine the application of prerequisites, grounds and conditions of both forcible and non-forcible measures, as well as those based on the unreasonableness of criminal proceedings and legal measures against legal entities.

Basic content. Familiarity with the content of certain provisions of section XIV-1 of the General part of the Criminal Code of Ukraine gives grounds to argue that the application of compulsory measures of criminal nature in relation to legal entities (fine, confiscation of property and liquidation) requires the legal enforcer to state the fact:

1) committing any of the crimes provided in Articles 109, 110, 113, 146, 147, Part 2-4, 159-1, 160, 209, 260, 262, 306, Part 1 and 2, 368-3, Part 1 and 2, 368-4, 369, 369-2, 436, 437, $438,442,444,447$ of the Criminal Code of Ukraine by an authorized person on behalf of and in the interest of a legal entity

2) committing any of the crimes provided for in Articles 258-258-5 of the Criminal Code of Ukraine by an authorized person on behalf of the legal person;

3) failure to fulfill the obligations imposed on an authorized person by the law or the constituent documents of the legal entity to take measures to prevent corruption which led to commiting any of the crimes provided in Articles 209 and 306, Part 1 and 2. 368-3, Part 1 and 2, 368-4, 369 and 369-2 of the Criminal Code of Ukraine.

Ponomarenko notes that the basis of application of these other measures of criminal nature for legal entities is related to certain behavior of individuals, since the legal entity is not recognized as the subject of a crime, that is, the subject capable of independently committing a criminal wrongful prohibition (crime) [1, p. 478]. In view of this, some scientists state that while committing a crime on behalf and in the interest of a legal entity, an authorized person may act even in joint paticipation with other criminal subjects (for example, an authorized per- 
son involved in providing the unlawful benefit to a mediator), but in this case the authorized person must be his executor (coexecutor) [3, p. 298].

Therefore, criminal legal measures can be applied to a legal entity only in the presence of a certain (specifically defined by law) composition of the crime in the actions of an authorized individual. In this regard, the statement is worth supporting that the subject as per legal entity being proved in criminal proceedings has a specific legal nature in comparison with other types of subjects identified at the theoretical level. On the one hand, it is derivative, since the circumstances that make up its content begin to be established only in the presence of signs of a certain criminal offense in the actions of the authorized person of the legal entity, and their further proof automatically loses its meaning in case criminal proceedings against it are closed. On the other hand, the existence of grounds for criminal prosecution of an authorized person of a legal entity for crimes under Article 96-3 of the Criminal Code of Ukraine, is a prerequisite for proving additional, in comparison with Article 91 of the Criminal Procedure Code of Ukraine, to determine the type and size of a criminal-and-law measure applicable to a legal entity [4, p. 64, 112-112].

In the legal literature it is stated that the grounds to use the measures of criminal nature to a legal entity, provided in section XIV-I of the General part of the Criminal Code of Ukraine, are characterized by two aspects:

1) substantive and procedural. The substantive legal aspect is reflected in the provisions of Article 96-3 of the Criminal Code of Ukraine. The procedural aspect lies in the fact that the procedural basis for the application of crimina and law measures against legal entities is the conviction of a court against an authorized person who has committed a crime on behalf and in the interests of a legal entity [5, p. 8] Sometimes in the legal literature it is even stated that the procedural legal basis to use measures of a criminal nature to a legal entity is the entry into force of a guilty verdict of a court by which an authorized person is convicted for committing a crime on behalf (or on behalf and in the interests) of a legal entity Criminal Code of Crime [1, p. 480]. We cannot agree with this understanding of the procedural component of the application of criminal-law measures against a legal entity, since the procedural basis of such measures is not the conviction of a court against an authorized person of a legal entity, but the recognition of such an authorized person guilty of a crime and the commission of a crime (or) in the interest of the legal person. The verdict of the court is the procedural document in which the fact at the same time states that an authorized person commits a certain statutory crime and, as a consequence, the decision to apply a certain compulsory measure of criminal nature to such a legal entity. In this regard, it is hardly possible to agree that criminal law measures may be applied to a legal person after the entry into force of a conviction by a court of law, by which his authorized person is convicted of committing on behalf of and / or in the interests of a legal person. persons identified in the Criminal Code, because such a conclusion follows from the above doctrinal position. Hence the conviction of the court is not a procedural basis for the application of measures of a criminal nature in relation to a legal entity, but a procedural document in which they find their external manifestation of specific compulsory measures of a criminal nature in relation to a legal entity to be enforced in the event of such a sentence being enforced. together with the execution of punitive and other non-punitive measures of a criminal nature against an authorized natural person. By the way, the order of execution of judicially ordered criminal actions against legal entities is in the initial stages of scientific investigation and will surely be the subject of our further investigations.

But is it sufficient for a forcible measure to be imposed on a legal entity to establish solely the fact of the commission of an authorized person on behalf of and / or in the interests of a legal entity of a particular (specifically defined by law) crime? It seems that it is not. The fact is that, in the presence of the above grounds, compulsory measures of a criminal nature in relation to a legal entity may be applied to such a person only in the absence of circumstances that preclude the decision to apply such measures to the legal person, as well as grounds for the release of the legal person from enforcing the criminal measures [6, p. 246]. This point of view is supported by other researchers. The latter ones note that in the criminal proceedings the proof of commiting the crimes by an authorized individual provided in Article 96-3 of the Criminal Code of Ukraine, is not the sole (exclusive) prerequisite (basis) for bringing a legal entity to justice within the framework of the criminal law [4, p. 65].

It should be noted that circumstances which exclude the possibility of deciding on the application of some of the compulsory measures of criminal nature in relation to the legal entity, have already been the subject of scientific research of domestic scientists. Such circumstances constitute the facts provided in the Criminal Code of Ukraine, in the presence of which it is impossible or prohibited to apply measures of a criminal nature in the form of a fine or 
liquidation (together with confiscation of property) in the case of commiting certain crimes by certain authorized persons. For example, according to Part 1 of Article 96-4 of the Criminal Code of Ukraine to legal entities belonging to the public sphere, such basic measure of criminal nature as a fine may not be applied in the case of commiting any crime provided by points 1 and 2 of part one of Article 96-3 of the Criminal Code Of Ukraine [8, p. 231-232].

As for such a condition for the application of compulsory measures of a criminal nature in relation to a legal entity as no grounds for exempting a legal person from applying the forcible measures of a criminal nature, it should be mentioned the following.

Exemption of a legal entity from applying of criminal - and-law measures in connection with the expiration of the limitation period (Articles 96-5 of the Criminal Code of Ukraine) can be evaluated only positively. Legislative regulation of the limitation period, which is associated with the impossibility of applying to the legal person compulsory measures of a criminal nature, due to the fact that eventually the commission of a socially dangerous act by an authorized person becomes non-essential. Moreover, long after the crime has been committed, it is difficult, if it is at all possible, to ensure the comprehensiveness and completeness of the investigation, since the evidence may be lost, the facts and circumstances surrounding the crime may be forgotten by witnesses [2, p. 344-345]. Finally, in the light of these circumstances, further pretrial investigation is simply inappropriate.

It should be noted that the practical implementation of the exemption of a legal entity from applying criminal and law measures against the legal entity in connection with the expiration of the limitation period (Articles 96-5 of the Criminal Code of Ukraine) requires the court to establish the prerequisites and grounds. Obviously, their absence is not a barrier to using the forciblemeasures against a legal entity. On the other hand, with their presence - the activity of the law enforcer, aimed at implementing the prescriptions provided by Article 96-6 - 96-9 of the Criminal Code of Ukraine, loses its meaning.

It should be noted that in the legal literature there is no consensus on the understanding of the cause and factor of exempting a legal entity from using of compulsory measures of criminal law nature. Thus, Mitrofanov notes that the substantive legal basis for the application of this type of release is a significant reduction of the public danger of the crime committed in connection with the expiration of a long time and the loss of public danger by a person who has prolonged law-abiding behavior after committing a crime [2, p. 345].

According to Yashchenko, the implementation of this measure of criminal influence is possible if there are, in the aggregate, prerequisites, grounds and conditions. The prerequisite for the release of a legal person from applying measures of criminal nature includes the substantive and procedural aspect. In the material aspect, such a prerequisite is the fact of the commission of a crime specified in Article 96-3 of the Criminal Code of Ukraine. In the procedural aspect a prerequisite is the solving of criminal proceedings against an authorized person by releasing from criminal responsibility under Article 49 of the Criminal Code of Ukraine or by releasing from punishment in connection with the expiration of limitation period under Part 5 of Article 74 of the Criminal Code of Ukraine, if the authorized person objected to releasing from criminal liability under Article 49 of the Criminal Code of Ukraine (Part 3 of Article 285 of the Criminal Procedure Code of Ukraine) and the guilt was nevertheless proved in full in the general procedure of criminal proceedings. The material basis for exempting a legal entity from the applying the measures of criminal nature is the expiration of statutory limitation periods. The conditions are the failure of the authorized person to re-commit any of the crimes specified in Article 96-3 of the Criminal Code of Ukraine, as well as the absence of the fact of the concealment of the authorized person from the pre-trial investigation officials and the court together with the fact of lack of information about the location of the authorized person [7, p. 301-308].

In our opinion, the cause and factor of the implementation of this other measure of criminal nature is a set of legal preconditions and established grounds. Such a prerequisite is, first of all, the proof of the commission by the authorized person in the interests and (or) on behalf of any of the crimes defined in Article 96-3 of the Criminal Code of Ukraine in the court . In this case there is a certain transformation of the grounds for applying measures of criminal nature to the legal entities into the prerequisite for exempting from applying such measures.

In addition, according Mitrofanov, the limitation period, provided in Article 96-5 of the Criminal Code of Ukraine, coincide with the terms of limitation of execution of the indictment against the authorized individual (Article 80 of the Criminal Code of Ukraine) and terms of bringing them to criminal responsibility (Article 49 of the Criminal Code of Ukraine) [2, with. 344], we are also inclined to support Yashchenko, quoted above, that the prerequisite of 
this type of release is also the procedural aspect defined by him.

As for the actual ground for the release of a legal entity, both private and public, from applying of the foregoing compulsory measures of a criminal nature, we are inclined to believe that such a basis is a combination of a certain event and the relevant behavior of a person together with the statement of a particular circumstance. Such a definite event is the end of the terms defined in Part 1 of Article 96-3 of the Criminal Code of Ukraine. Their action commences from the day of committing any crime referred to Article 96-3 of this Code by the authorized person and ends with the verdict coming into the force. There are the following terms:

1) three years in the case of a petty crime ;

2) five years in the case of a misdemenour;

3 ) ten years in the case of a serious crime;

4) fifteen years in the case of a felony .

The second component of the grounds for exempting a legal entity from applying the measures of a criminal nature is the following type of post-criminal behavior of the authorized person, together with the statement of the available individual circumstance:

1) failure to conceal the authorized person who committed any crime specified in Article 96-3 of this Code on the purpose of evading criminal liability and the availability of information on the location of such authorized person;

2) not recommitting any crime from the list specified in Article 96-3 of the Criminal Code of Ukraine.

Conclusions. The foregoing allows us to draw the following conclusions:

1) measures of criminal nature in relation to legal entities are considered in the aggregate: a) forcible measures of criminal nature in relation to legal entities (fine, confiscation of property, liquidation); b) measures based on the unreasonableness of carrying out further criminal proceedings against a legal entity (exemption of a legal entity from the application of measures of a criminal nature);

2) applying the forcible measures of a criminal nature in relation to a legal entity is possible not only in the presence of the grounds established by the court apply such measures, but also in the absence of circumstances precluding the decision to apply such measures to the legal entity, as well as the grounds for releasing a legal entity from applying the compulsory measures of criminal nature;

3) the cause and factor complex of the implementation of the measure based on the unreasonableness of further criminal proceedings against the legal entity (Articles 96-5 of the Criminal Code of Ukraine) is a set of prerequisites (statement of the fact of the commission of a crime determined by law, as well as releasing an authorized person from criminal liability or punishing in connection with the expiration of the limitation period) and the grounds, the content of which is a combination of a certain event and the appropriate behavior of a person together with the statement of a particular circumstance.

\section{References:}

1. Кримінальне право України: Загальна частина: підруч. / В. І. Борисов, В. Я. Тацій, В. І. Тютюгін та ін. ; за ред. В. Я. Тація, В. І. Борисова, В. І. Тютюгіна ; 5-е вид., перероб. і доп. Харків : Право, 2015. 528 с.

2. Митрофанов I. I. Актуальні проблеми регулювання відповідальності у кримінальному праві : монограф. Одеса : Фенікс, 2017. 450 с.

3. Науково-практичний коментар до Кримінального кодексу України ; за ред. М. І. Мельника, М.І. Хавронюка. 10-е вид., перероб. і доп. Київ: ДАКОР, 2018. 1368 с.

4. Панченко О. В. Кримінальне провадження щодо юридичної особи: дис. ... канд. юрид. наук : 12.00.09 / Нац. юрид. ун-т ім. Ярослава Мудрого. Харків, 2018. 203 с.

5. Провторов О. П. Заходи кримінально-правового характеру щодо юридичних осіб як інститут кримінального права України : дис. ... канд. юрид. наук : 12.00.08/ Ін-т держави і права ім. В. М. Корецького НАН України. Київ, 2019. 20 с.

6. Ященко А.М. Примусові заходи кримінального характеру щодо юридичних осіб: причини і чинники запровадження та ефективність застосування. Ефективність кримінального права: доктринальні, законодавчі та правоохоронні проблеми: Міжнар. наук.-практ. круглий стіл (м. Харків, 17 травня 2019 р.). Харків : Видавництво «Константа», 2019, с. 243-247.

7. Ященко А. М. Звільнення юридичної особи від застосування кримінально-правових заходів із закінченням строків давності: теоретико-прикладний аспект. Форум права. 2017. № 4. C. 300-308. URL: file: /// C: / Users / Admin / Downloads / ojWZb3Fe_xA8gVEANfWbADMR-cOf3JZs\% 20 (1).pdf.

8. Ященко А. М. Обставини, що виключають можливість застосування до юридичних осіб заходів кримінального характеру. Підприємництво, господарство і право. 2016. № 12. с. 227-232. 
1. Kryminal'ne pravo Ukrayiny: Zahal'na chastyna [Criminal Law of Ukraine: General part]: pidruch. / V. I. Borysov, V. Ya. Tatsiy, V. I. Tyutyuhin ta in. ; za red. V. Ya. Tatsiya, V. I. Borysova, V. I. Tyutyuhina ; 5-e vyd., pererob. i dop. Kharkiv : Pravo, 2015. 528 s. [in Ukr.]

2. Mitrofanov, I. I. (2017) Aktual'ni problemy rehulyuvannya vidpovidal'nosti u kryminal'nomu pravi [Actual problems of regulation of liability in criminal law]: monohraf. Odesa : Feniks, $450 \mathrm{~s}$. [in Ukr.]

3. Naukovo-praktychnyy komentar do Kryminal'noho kodeksu Ukrayiny [Scientific and practical commentary on the Criminal Code of Ukraine] ; za red. M. I. Mel'nyka, M.I. Khavronyuka. 10-e vyd., pererob. i dop. Kyyiv: DAKOR, 2018. 1368 s. [in Ukr.]

4. Panchenko, O. V. (2018) Kryminal'ne provadzhennya shchodo yurydychnoyi osoby [Criminal proceedings against a legal entity]: dys. ... kand. yuryd. nauk : 12.00.09 / Nats. yuryd. un-t im. Yaroslava Mudroho. Kharkiv, 203 s. [in Ukr.]

5. Provtorov, O. P. (2019) Zakhody kryminal'no-pravovoho kharakteru shchodo yurydychnykh osib yak instytut kryminal'noho prava Ukrayiny [Measures of Criminal Law Regarding Legal Entities as an Institute of Criminal Law of Ukraine]: dys. ... kand. yuryd. nauk : 12.00 .08 / In-t derzhavy i prava im. V. M. Korets'koho NAN Ukrayiny. Kyyiv, 20 s. [in Ukr.]

6. Yashchenko, A. M. (2019) Prymusovi zakhody kryminal'noho kharakteru shchodo yurydychnykh osib: prychyny i chynnyky zaprovadzhennya ta efektyvnist' zastosuvannya [Coercive measures of a criminal nature against legal entities: causes and factors of implementation and effectiveness of application]. Efektyvnist' kryminal'noho prava: doktrynal'ni, zakonodavchi ta pravookhoronni problemy: Mizhnar. nauk.-prakt. kruhlyy stil (m. Kharkiv, 17 travnya 2019 r.). Kharkiv : Vydavnytstvo «Konstanta», s. 243-247. [in Ukr.]

7. Yashchenko, A. M. (2017) Zvil'nennya yurydychnoyi osoby vid zastosuvannya kryminal'nopravovykh zakhodiv iz zakinchennyam strokiv davnosti: teoretyko-prykladnyy aspect [Exemption of a Legal Entity from the Application of Criminal Law Measures with Expiry of Limitation Periods]. Forum prava № 4. S. 300-308. URL : file: /// C: / Users / Admin / Downloads / ojWZb3Fe_xA8gVEANfWbADMRcOf3JZs\% 20 (1).pdf. [in Ukr.]

8. Yashchenko, A. M. (2016) Obstavyny, shcho vyklyuchayut' mozhlyvist' zastosuvannya do yurydychnykh osib zakhodiv kryminal'noho kharakteru [Circumstances that exclude the possibility of applying to the legal entities measures of a criminal nature]. Pidpryyemnytstvo, hospodarstvo i pravo. № 12 . s. 227-232. [in Ukr.]

\title{
Summary
}

In accordance with the analysis of the legal provisions of the section XIV-1 of the Criminal Code of Ukraine, as well as doctrinal definitions about content, grounds and conditions of application of measures of criminal nature in relation to legal entities, the preconditions, grounds and application of both forcible and unreasonable measures for further criminal proceedings against legal entities are defined.

Keywords: legal entity, prerequisite, basis, condition, application, measures of criminal law nature.

UDC 343.985

DOI: $10.31733 / 2078-3566-2019-5-237-242$

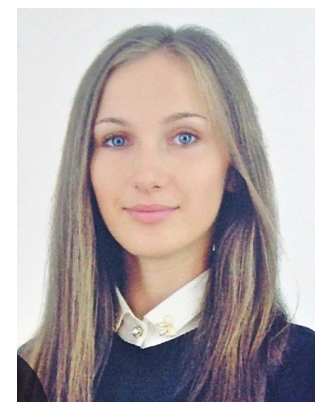

\author{
Anastasia SENKO $^{\complement}$ \\ Graduate student \\ (Dnipropetrovsk State University \\ of Internal Affairs)
}

\section{CRIMINAL PROVISION OF AN EXAMINATION DURING THE INVESTIGATION OF CITIZEN'S LUGGAGE THEFT COMMITED AT THE AIRPORT}

Анастасія Сенько. КРИМІНАЛІСТИЧНЕ ЗАБЕЗПЕЧЕННЯ ПРОВЕДЕННЯ ОГЛЯДУ ПІД ЧАС РОЗСЛІДУВАННЯ КРАДІЖОК БАГАЖУ ГРОМАДЯН, УЧИНЕНИХ В АЕРОПОРТУ. Наукова стаття присвячена висвітленню деяких аспектів проблемних питань розслідування крадіжок багажу громадян, учинених в аеропорту. Виокремлено наукові підходи до визначення поняття та структури криміналістичної характеристики кримінального правопорушення. Наголошено на значенні даної наукової категорії. Розглядаються особливості криміналістичного забезпечення проведення огляду для більш швидкого розслідування досліджуваної категорії кримінальних правопорушень. Автор зазначає, що огляд $є$ однією 3 найбільш розповсюджених слідчих (розшукових) дій при розслідуванні крадіжок багажу пасажирів в аеропортах.

\footnotetext{
(C) Senko A., 2019

k_ksmp@dduvs.in.ua
} 